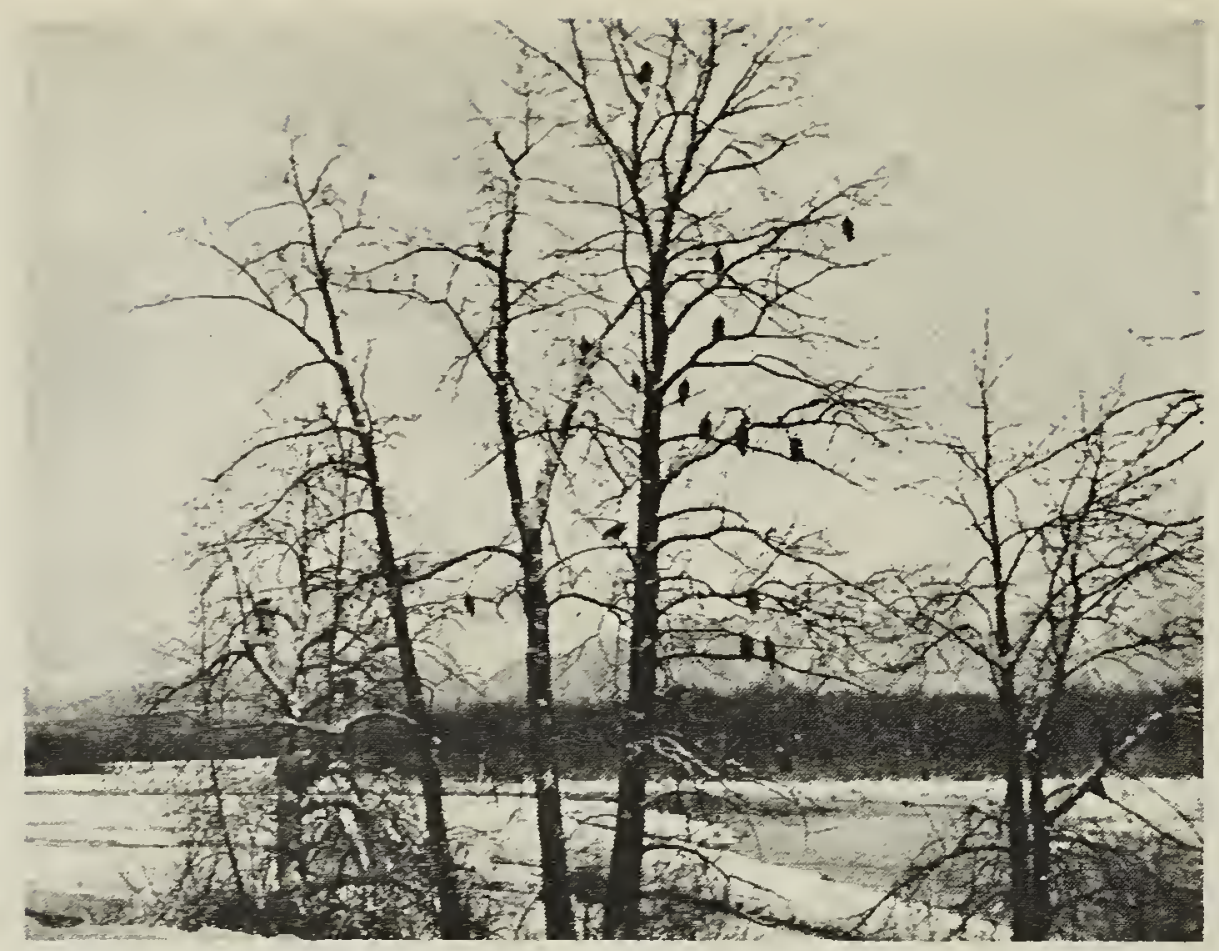

There are at least 22 Bald Eagles in this photograph. It was taken at Mile 3 on the Haines-Alaska Highway in January. 1973. by Susan Tubby, of Saskatoon. now living in Whitehorse, Yukon. This enlargement was made from part of a $16-\mathrm{mm}$. negative.

\section{A CORRESPONDENCE COURSE IN BIRD STUDY}

The Cornell Laboratory of Ornithology has produced a home study course, Seminars in Ornithology, that should appeal to every bird watcher who is interested in increasing the depth of his ornithological knowledge. Here in nine lessons is a college-level course in ornithology to be studied at home. In a very readable style, the course gives a substantial background for the enjoyment and appreciation of birds and encourages you to undertake study projects on your own. Titles of the lessons are: 1) A Preview of Birds: 2) The External Bird; 3) Birds in the Earthly Environment; 4) Birds on the Move; 5) The Internal Bird (Part 1): 6) The Internal Bird (Part 2); 7) Behavior of Birds; 8) Birds from Nests to Flight: 9) Birds and You.

Your Text: Each seminar is written by leading American ornithologists and lavishly illustrated by well-known bird artists.

Your Participation: The home study course is organized sequentially, with each lesson mailed to you for study and completion before progressing to the next one. You simply insert the looseleaf pages into a three-ring binder.

Your Progress: You are aided in assessing your understanding of ornithology by question sheets provided with each seminar. An instructor at the Laboratory of Ornithology personally corrects your question sheets.

Your Procedure: Upon enrolling in the home study course and paying the registration fee, you will receive Seminar I, with questions and an order form for Seminar II. When your answered questions and payment for Seminar II are received at the Laboratory, the instructor corrects your questions and the next lesson is mailed to you, and so on in rolling fashion through Seminar VIII. When you have completed eight lessons, the last one (Seminar IX) will be sent to you free.

Your Certification: Upon completion of eight lessons and question sheets, you will receive a special certificate signed by the Director of the Laboratory of Ornithology acknowledging your successful participation in the home study course.

In March, 1973, there were about 60 Canadians among the 600 persons enrolled. The course can be started at any time and lessons can be completed 
as quickly or slowly as each student wishes.

Payment: Select one of two plans: 1) Plan 1. \$88.00 in advance. You may purchase the first eight seminars now at $\$ 11.00$ each minus the registration fee. You will receive the ninth seminar free. 2) Plan 2. $\$ 95.00$. You may purchase the first eight seminars one at a time at $\$ 11.00$ each plus a registration fee of $\$ 7.00$. You will receive the ninth seminar free.

If interested in more information or enrolling, write: Seminars in Ornithology, Cornell Laboratory of Ornithology, 159 Sapsucker Woods Road, Ithaca, New York 14850. Cheques should be made payable to the Cornell Laboratory of Ornithology.

\section{THIRTEENTH}

\section{ANNUAL NESTBOX REPORT Of the Brandon Junior Birders}

\section{by JACK LANE* and CHRISTOPHER MARTIN**}

Due to the very mild and open winter of $1972-73$, our club set out a record number of nestboxes, over 650 before the year's first bluebirds appeared this spring. Most of the boxes were built and donated by a retired railroader, W. E. Forsyth. Due to his continuing efforts, our weekly winter nest-building bees are now finished. With a present total of over 4,100 nestboxes scattered along more than 1,400 miles of nestline, it is no longer practicable to attempt a check of the nests and, beginning with this report, we will estimate all nestings of bluebirds.

Noteworthy this year is a decrease in the number of nestings of the Eastern Bluebird. Some effort was made to check the nestings of this species but it was not comprehensive, and a combined check and estimate shows a drop of 25 nestings from last year. We believe this may be attributed to the increasing numbers of nestboxes being set out by two groups in the Selkirk-Winnipeg areas. Since our local Eastern Bluebirds pass that way in spring migration, it appears quite likely that more and more of them will stay in eastern Manitoba to raise their families.

One of our new nestlines, running north from Kirkella to north of Russell, has James Spear in charge of it and others around Russell. The highlight of his report is the nesting of a pair of Easterns in the Assiniboine Valley west of Russell. After enlisting the aid of our local biologist, Larry Bidlake, in the fight against the plague that decimated the first-broods of Mountain Bluebirds both in 1970 and 1972, the malady did not appear this year. We are inclined to blame this everyther-year epidemic on blood-sucking Black flies. Bidlake had provided us with a spray to be used in the nestboxes.

This year also yielded our fifth example of a male hybrid. Rather late in the summer he took over a nestbox on the Hooke Ranch, south of Camp Hughes; he was mated to a normal Eastern female that laid four eggs. Since two earlier crosses between a hybrid male and a normal Eastern hen had produced only one paby from a total of 11 eggs, we thought this 1973 pair might have infertile eggs. They confounded us by hatching all four eggs. 